\title{
Nursing students' use of technology enhanced learning: A longitudinal study
}

\author{
Ann Wilkinson, J ulia Roberts, Alison While \\ School of Nursing and Midwifery, King's College London, UK
}

Correspondence: Ann Wilkinson. Address: Department of Health Policy and Management, Florence Nightingale School of Nursing and Midwifery, King's College London, James Clerk Maxwell Building, 57 Waterloo Road, London SE1 8WA, UK. Telephone: 44-207-848-3708. Email: ann.wilkinson@kcl.ac.uk.

Received: July 12, 2012

DOI : $10.5430 /$ jnep.v3n5p102
Accepted: October 15, $2012 \quad$ Online Published: December 14, 2012

URL: http://dx.doi.org/10.5430/jnep.v3n5p102

\section{Abstract}

Background: Nurses are expected to be information and communication technology (ICT) literate at registration but, despite the growth of social uses of technology, little is known of the views of students on the use of technology enhanced learning. The purpose of this study was to explore the experience and confidence of first year pre-registration nursing students with information and communication technologies and technology enhanced learning.

Methods: A prospective longitudinal survey design with multiple data collection strategies was employed. Crosssectional surveys using a new ICT and Education Scale at three time-points were used to collect data. The target population were first year UK nursing students $(n=458)$; of those $287(41.7 \%)$ participated in the initial baseline survey.

Results: There were three main findings. First, more than half of the respondents (67\%) reported that they were not confident with aspects of information literacy and were not prepared for technology enhanced learning (60\%) as they entered university and these aspects showed least change through time. Second, from varied starting points at baseline, respondents' experience and confidence with ICT skills showed different trajectories over time. Third, there was some evidence that demographic profile was related to use and acceptance of ICT in the educational context.

Conclusions: There is some evidence that nursing students find it difficult to negotiate the boundaries between their pre-university experience with technologies and that of education and practice. In a rapidly changing technology environment this has implications for curriculum planning in the first six months of a programme of study as well as student/staff preparation for technology enhanced learning.

\section{Key words}

Attitudes, Information technology, Technology enhanced learning, Nurse education, Survey design

\section{I ntroduction}

The Prague Declaration ${ }^{[1]}$ recognised the importance of information literacy in both education and the workforce. International and national reports have continued to extend the range of skills students will need to develop ${ }^{[2,3]}$. Healthcare is increasingly technology dependent, consequently nurses in all regions of the world are expected to develop their information and communication technology (ICT) skills ${ }^{[4]}$. The use of ICT in nursing education is receiving attention 
internationally ${ }^{[5-7]}$ and specifically regarding the challenges which this poses for both staff and students ${ }^{[7,8]}$. Indeed, there is a risk of both student and staff attrition if the impact of ICT on education is not well understood ${ }^{[6]}$.

One of the requirements for educated nurses in the future will be to develop what is now referred to as digital media literacy, critical thinking skills and the ability to problem solve ${ }^{[3]}$. In addition, access to information via various technologies is seen as an important precursor to increasing educational capacity in remote or under-served areas ${ }^{[9]}$. Strategic direction in the United Kingdom (UK), for example, encouraged greater connectivity across educational sectors and wider sharing of technology enhanced learning resources ${ }^{[10,11]}$ with the suggestion that ICT should pervade all aspects of the student experience ${ }^{[12]}$. The UK Department of Health has extended this to healthcare staff with a strategy for technology enhanced learning ${ }^{[13]}$. Over the past 15 years technology enhanced learning in the broadest sense has moved from being project driven to being part of institutional strategy. Despite this there is little evidence concerning the student perspective on technology enhanced learning ${ }^{[14-16]}$.

In North America and Australia there have been increased demands for qualified nurses and these have been met by enabling diverse routes of entry. In addition, recruitment of ethnic minorities has increased. Some of this growth has been made possible by flexible and online modes of learning ${ }^{[9,17]}$. The consequences for different groups of students are not yet reported in the literature. The expanding ICT skills of healthcare students have been reported internationally ${ }^{[18-21]}$ but little information concerning their confidence in applying those skills to technology enhanced learning has been reported. Researchers and commentators have questioned whether students have more advanced skills in finding and managing information ${ }^{[22-28]}$.

Finally, study populations are treated as homogeneous and little emerges concerning the impact of cultural differences such as race, ethnicity, language, educational level, work experience or social circumstances ${ }^{\text {[29] }}$. The purpose of this study was, therefore, to investigate pre-registration nursing students' confidence and skill with computers, experience with information and communication technologies and attitudes to computers in education (technology enhanced learning) used as a supplement to face to face teaching during a first year of university education.

\section{Methods}

\subsection{Design}

A prospective longitudinal survey design was selected because weaknesses of previous studies included cross-sectional measurement of attitudes and exploration of views or experience of students rather than trend analysis ${ }^{[16]}$. A single study design was adopted with cross-sectional surveys at three time points (Baseline, Time 1, Time 2).

\subsection{Setting}

The study site was a large metropolitan university in the UK offering adult, mental health and children's pre-registration nursing education.

\subsection{Participants}

The total entry cohort of pre-registration nursing students in the 2004-5 academic year was invited to participate. The study population differed from the national population of students admitted to programmes in the UK ${ }^{[30,31]}$ with respect to age, ethnic diversity and prior educational achievement and was, therefore, not representative of the national population of nursing students. 


\subsection{Data collection methods}

A 51 item self-report instrument was developed and validated. An expert reference group and two students were recruited to rank and reduce potential items (111) and group within domains. The instrument was validated during a pilot study $(\mathrm{n}=60$, response $67 \%)$ and test-retest survey $(\mathrm{n}=70 \text { response } 78 \% \mathrm{~T} 1,65 \% \mathrm{~T} 2)^{[32]}$. Individual items were analysed using Cohen's Kappa ( $\kappa)$ adjusted proportion of agreement with variable results, the internal consistency of subscales was measured both in the test-retest survey and main survey (T1) and found to be acceptable $(>0.70)$. Removing items from scales made only marginal improvements to reliability.

The instrument was administered to all students on three occasions during the first year to yield information on confidence and skills with computers, experience with ICT and attitudes to using ICT in education and trends over time. The instrument was designed for both online and paper administration. Only baseline data collection was completed online. As this was a time-point study no follow-up of non-response was undertaken and later data collection took place in classrooms. Internal consistency was measured at T1 in the main study. The reliability was reasonable when applied to the more diverse and larger main study sample. This indicates that subscales might be enhanced by further work with a larger sample.

\subsection{Ethical considerations}

The university ethics committee gave approval for the study. A small incentive was offered; a prize gift token at each time point. Consent was implied by completion of the questionnaire. Student identification numbers were used to match questionnaires over the phases of the study but this resulted in some questionnaires being discarded where these were not supplied or were misreported. Institution data managers provided access to anonymous population data which served to identify patterns of non-response. Ethics committee stipulations meant that the researcher (AW) engaged participants after the teaching session and students were free to leave while the instrument was circulated. The information sheet, recruitment message and verbal instructions stated that completion of the survey was voluntary.

\subsection{Data collection}

Newly enrolled first year students were split into two cohorts for their studies and they were invited to participate in the main study at two separate sessions during the first weeks of semester one. A short explanation of the research was provided and information sheets were distributed. A reminder email was sent to all students immediately prior to data collection. Lecturers administered the baseline survey in term one, following a taught session in computer rooms. Despite preparation, including a pack of instructions, lecturers did not present the research uniformly. Under half of the cohort $(\mathrm{n}=191)$ responded to the baseline survey. The researcher (AW) administered the survey at Time 1 (T1) and Time 2 (T2). $\mathrm{T} 1$ occurred five months after baseline and $\mathrm{T} 2$ five months later. The overall response was lower than at baseline ( $\mathrm{n}=153)$, of these respondents 17 provided no ID. T2 took place as students returned from their summer clinical placement to enter the second year of the programme. The survey instrument was amended by the addition of three additional items to establish usability of e-journals, use of computing rooms and computer use in clinical placements. The procedures followed those at $\mathrm{T} 1$.

\subsection{Data analysi}

Data analysis was conducted using SPSS $12-15$ for Windows ${ }^{[33]}$. Pilot data were used to test the coding frames. For demographic variables we formed frequency tables and examined relationships among them using two-way frequency tables and the Pearson Chi-squared test. We also looked at the relationship between key variables: confidence with computers; ICT skills; experience with computers and attitudes to ICT in education and the demographic variables. For each scale, since all were ordinal we used the Mann Whitney and Kruskal Wallis tests as appropriate. Two way ANOVAs were also performed on the ranked scale values to examine the effects of several demographic variables. 


\section{Results}

\subsection{Participant flow}

The total entry cohort was 458 students. The response rate at individual time points was variable, which introduced the potential for bias. There was also sample attrition over the three time points, which resulted in different proportions of some groups responding at each time point (see Table 1). White students, those aged 19 years and under and Children's Branch respondents provided the lowest response at all time points.

Table 1. Sample response by demographics at each time point

\begin{tabular}{|c|c|c|c|c|c|c|c|c|}
\hline & \multicolumn{2}{|c|}{ Baseline } & \multicolumn{2}{|l|}{ T1 } & \multicolumn{2}{|l|}{$\mathbf{T} 2$} & \multicolumn{2}{|c|}{ Whole year group* } \\
\hline & $\mathbf{n}$ & $\%$ & $\mathbf{n}$ & $\%$ & $\mathbf{n}$ & $\%$ & $\mathrm{n}^{*}$ & $\%$ \\
\hline \multicolumn{9}{|l|}{ Programme } \\
\hline $\mathrm{BSc}$ & 30 & 16 & 29 & 22 & 37 & 30 & 113 & 24 \\
\hline DipHE & 161 & 84 & 105 & 78 & 85 & 70 & 354 & 76 \\
\hline \multicolumn{9}{|l|}{ Gender } \\
\hline Male & 29 & 15 & 17 & 13 & 22 & 18 & 58 & 12 \\
\hline Female & 162 & 85 & 118 & 87 & 100 & 82 & 410 & 88 \\
\hline \multicolumn{9}{|l|}{ Ethnicity* } \\
\hline White & 90 & 47 & 60 & 44 & 66 & 54 & 238 & 51 \\
\hline BME & 101 & 53 & 75 & 56 & 56 & 46 & 218 & 47 \\
\hline \multicolumn{9}{|l|}{ Age } \\
\hline 19 years or younger & 43 & 22 & 23 & 17 & 22 & 18 & 121 & 26 \\
\hline 20-26 years & 51 & 27 & 36 & 27 & 32 & 26 & 132 & 28 \\
\hline $27-35$ years & 40 & 21 & 35 & 26 & 36 & 30 & 108 & 23 \\
\hline 36 years or older & 57 & 30 & 41 & 30 & 32 & 26 & 107 & 23 \\
\hline \multicolumn{9}{|l|}{ Prior education*† } \\
\hline A Level and GCSE & 64 & 34 & 43 & 32 & 40 & 33 & - & - \\
\hline NVQ, HNC, HND & 37 & 20 & 28 & 21 & 36 & 30 & - & - \\
\hline Access course & 62 & 33 & 55 & 41 & 35 & 29 & - & - \\
\hline Degree/Postgraduate & 27 & 14 & 9 & 7 & 10 & 8 & - & - \\
\hline \multicolumn{9}{|l|}{ Branch* } \\
\hline Adult & 141 & 74 & 105 & 78 & 78 & 64 & 331 & 71 \\
\hline Child & 11 & 6 & 8 & 6 & 16 & 13 & 65 & 14 \\
\hline Mental Health & 39 & 20 & 21 & 15 & 28 & 23 & 70 & 15 \\
\hline
\end{tabular}

- missing data; † A level, Advanced Level; GCSE, General Certificate of Secondary Education; NVQ, National Vocational Qualification; HNC, Higher National Certificate; HND, Higher National Diploma; Access, Access to Higher Education Diploma.

\subsection{Demographic data}

Table 2 summarises demographic data. Respondents were aged 17 - 55 years with a mean age of 28.3 years, with 74 (26\%) being aged 36 years or older (range $=38, S D=9$ ). Just over half of the sample $(51 \%, n=145)$ were 27 years or older on enrolment.

White British and European respondents ( $\mathrm{n}=148,52 \%)$ formed the largest ethnic group. There was no significant difference in ethnicity between the cohort population and the study sample. Other ethnic groups included Black British of African origin ( $n=96,33 \%$ ), and 43 (15\%) Black British Caribbean, other Black, Asian or mixed ethnic origin. Respondent categories were collapsed into two: White and Black, Asian or mixed ethnicity (BME). 
Table 2. Demographic details of sample $(n=287)$

\begin{tabular}{|c|c|c|c|}
\hline Item & $\mathbf{N}$ & $\%$ & Pop \% \\
\hline \multicolumn{4}{|l|}{ Age } \\
\hline$<19$ years & 67 & $23 \%$ & $26 \%$ \\
\hline 20-26 years & 75 & $26 \%$ & $28 \%$ \\
\hline 27-35 year & 71 & $25 \%$ & $23 \%$ \\
\hline $36+$ years & 74 & $26 \%$ & $23 \%$ \\
\hline Total & 287 & $100 \%$ & \\
\hline \multicolumn{4}{|c|}{ Mean age $=28.3$ years } \\
\hline \multicolumn{4}{|l|}{ Gender } \\
\hline Female & 244 & $85 \%$ & $88 \%$ \\
\hline Male & 43 & $15 \%$ & $12 \%$ \\
\hline Total & 287 & $100 \%$ & \\
\hline \multicolumn{4}{|l|}{ Programme } \\
\hline Degree & 66 & $23 \%$ & $24 \%$ \\
\hline \multirow[t]{2}{*}{ Diploma } & 220 & $77 \%$ & $76 \%$ \\
\hline & 286 & $100 \%$ & \\
\hline Missing data & 1 & & \\
\hline \multicolumn{4}{|c|}{ Prior Education } \\
\hline A Level/GCSE & 100 & $35 \%$ & \\
\hline Access Course & 95 & $33 \%$ & \\
\hline Vocational & 55 & $20 \%$ & \\
\hline Graduate & 35 & $12 \%$ & \\
\hline Total & 285 & & \\
\hline Missing data & 2 & & \\
\hline \multicolumn{4}{|l|}{ Ethnicity } \\
\hline White & 148 & $52 \%$ & $51 \%$ \\
\hline BME & 139 & $48 \%$ & $47 \%$ \\
\hline Total & 287 & $100 \%$ & \\
\hline \multicolumn{4}{|c|}{ Branch of Nursing } \\
\hline Adult & 206 & $72 \%$ & $71 \%$ \\
\hline Child & 30 & $11 \%$ & $15 \%$ \\
\hline \multirow[t]{2}{*}{ Mental Health } & 50 & $17 \%$ & $14 \%$ \\
\hline & 286 & $100 \%$ & \\
\hline Missing data & 1 & & \\
\hline
\end{tabular}

Note. Pop \% percentage of cohort population

Comparison of the previous educational experience of respondents from different ethnic backgrounds revealed differences. BME respondents were more likely to have undertaken an Access to Higher Education Diploma (Access) course $(n=76,80 \%)$ or vocational education $(n=38,69 \%)$ than White respondents $(n=19,20 \%$ and $n=17,31 \%$ respectively). White respondents were more likely to have taken traditional academic routes into higher education $(\mathrm{n}=85$, 85\%). Overall, 35\% had entered from school and 33\% had taken an Access course. The difference between the two respondent groups was statistically significant $\left(\chi^{2}=99.3,3 \mathrm{~d} f, p<0.0005\right)$. White and BME students were likely to have had different previous educational experiences, with White students pursuing traditional educational pathways and BME students entering university with a range of qualifications later in life.

BME respondents tended to be older (mean age $=32.9$ years) than White respondents (mean age $=24.1$ years) $\left(\chi^{2}=60.8,3 \mathrm{~d} f\right.$, $p<0.0005)$. Table 3 illustrates the different age profile of respondents. 
Table 3. Ethnicity by age

\begin{tabular}{llllll}
\hline \multirow{2}{*}{ Ethnicity } & Age Group & & & \\
\cline { 2 - 6 } & $<\mathbf{1 9}$ years & $\mathbf{2 0 - 2 6}$ years & $\mathbf{2 7 - 3 5}$ years & $\mathbf{3 6}+$ years & Total \\
\hline White & $55(82 \%)$ & $44(59 \%)$ & $36(51 \%)$ & $13(18 \%)$ & $148(52 \%)$ \\
BME & $12(18 \%)$ & $31(41 \%)$ & $35(49 \%)$ & $61(82 \%)$ & $139(48 \%)$ \\
Total & $67(100 \%)$ & $75(100 \%)$ & $71(100 \%)$ & $74(100 \%)$ & $287(100 \%)$ \\
\hline
\end{tabular}

\subsection{Survey results}

Descriptive and comparative results for the cohort are presented in the following sections. The aim of the analysis was to answer questions about nursing students namely: whether they perceive that they are equipped with the necessary skills to access computers and the Internet for learning; their views on the use of computers and the Internet for learning and does their experience using computers and the Internet for learning change over time?

The greatest differences between groups were found at Baseline and use and acceptance remained somewhat different at $\mathrm{T} 1$, however, by $\mathrm{T} 2$ there was some convergence. There was variation by programme, age, prior education, ethnicity and branch of nursing concerning aspects of confidence, skill and attitude to ICT and ICT in education.

\subsection{Confidence with computers}

The scores of confidence with computers (four items) were calculated for each respondent at the three time points. Overall a small median increase was observed from baseline to T1, but no change from $\mathrm{T} 1$ to $\mathrm{T} 2$. However these median movements masked individual rises and falls. Overall, respondents reported an increase in confidence between Baseline and T2, $(\mathrm{Z}=-2.6, p=0.010)$.

BSc respondents, however, reported greater confidence and remained more confident until T2 (see Figure 1). The difference between BSc and Diploma in HE (DipHE) respondents was significant at Baseline ( $\mathrm{U}=1724 p=0.014)$ and T1 (U=1084, $p=0.038$ ) while respondents' data converged at $\mathrm{T} 2$.

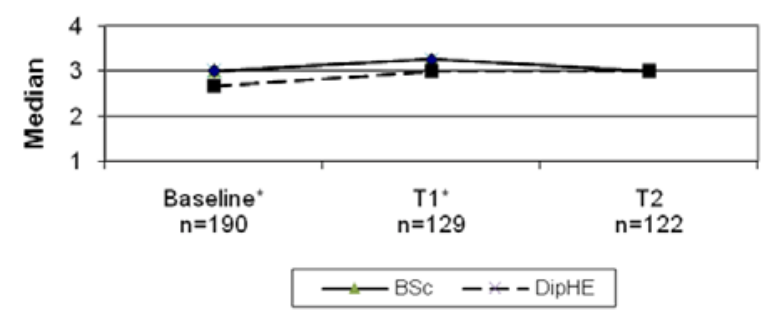

Figure 1. Confidence with computers and programme

\subsection{CT skills}

We categorised single item self-rating ICT skills into low, medium and high. Just over one third (34\%) of the sample rated their skills highly at baseline and this rose to $40 \%$ at $\mathrm{T} 1$, and $44 \%$ at $\mathrm{T} 2$. There were significant differences by programme $(\chi 2=5.11 \mathrm{~d} f, p=0.023)$ with BSc. students reporting more confidence in their ICT skills. Similarly, graduates and A level/GCSE respondents $\left(\chi^{2}=6.1,2 \mathrm{~d} f, p=0.048\right)$, White respondents $\left(\chi^{2}=6.2,2 \mathrm{~d} f, p=0.045\right)$ and those 26 years of age or under $(\chi 2=16.2,6 \mathrm{~d} f, p=0.013)$ were also more sure of their skills.

Respondents reported becoming more confident in 10 specific ICT skills over the three time points, however, there was very little difference between $\mathrm{T} 1$ and $\mathrm{T} 2$ and in a number of the skills respondents reported becoming slightly less 
confident. Respondents, for example, were not universally confident with the more complex skills, such as using bibliographic databases and these showed the lowest confidence ratings over the three time points.

The mean scores of ICT skills (e.g. being able to save a document to a folder and attaching a file to an email) were calculated for each respondent at the three time points and showed a statistically significant increase in reported confidence from Baseline to T1 $(\mathrm{Z}=-4.8, p<0.0005)$ and $\mathrm{T} 2(\mathrm{Z}=-2.5, p=0.013)$ but no difference between $\mathrm{T} 1$ and $\mathrm{T} 2$ (see Figure 2).

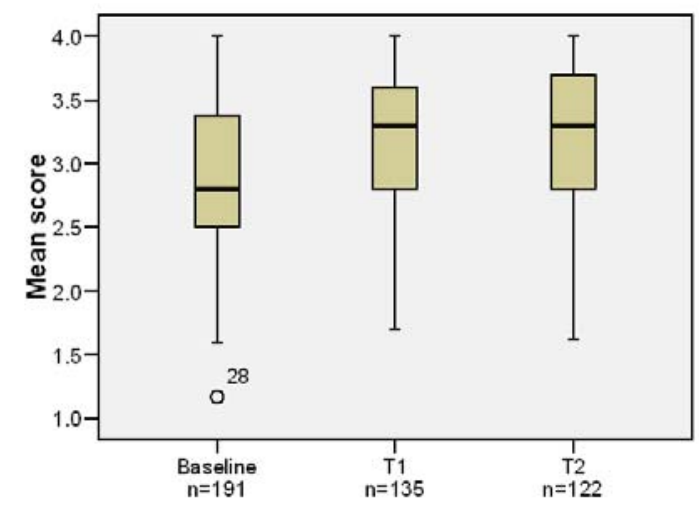

Figure 2. ICT skills

Respondents, who were aged 26 years or less, were on the BSc programme, were White and those had followed traditional routes into education, reported higher ICT skills across the three time points (see Table 4). Respondents on the Mental Health Branch of nursing reported consistently lower ICT skills across the three time points.

Table 4. ICT skills and demographics

\begin{tabular}{llll}
\hline Item & $\begin{array}{l}\text { Baseline } \\
\mathbf{n}=191\end{array}$ & $\begin{array}{l}\mathbf{T} 1 \\
\mathbf{n}=\mathbf{1 3 5}\end{array}$ & $\begin{array}{l}\text { T2 } \\
\mathbf{n}=\mathbf{1 2 2}\end{array}$ \\
\hline Age & $\mathrm{H}=10.3,3 \mathrm{df}, p=0.016$ & $\mathrm{H}=5.1$ 3df, $p=0.16 \mathrm{NS}$ & $\mathrm{H}=10.7,3 \mathrm{df}, p=0.014$ \\
Programme & $\mathrm{H}=12.0,1 \mathrm{df}, p=0.001$ & $\mathrm{H}=3.21 \mathrm{df}, p=0.072 \mathrm{NS}$ & $\mathrm{H}=9.0,1 \mathrm{df}, p=0.003$ \\
Ethnicity & $\mathrm{H}=17.5,1 \mathrm{df}, p<0.0005$ & $\mathrm{H}=11.7,1 \mathrm{df}, p=0.001$ & $\mathrm{H}=6.8,1 \mathrm{df}, p=0.009$ \\
Prior Education & $\mathrm{H}=8.2,3 \mathrm{df}, p=0.042$ & $\mathrm{H}=11.3,3 \mathrm{df}, p=0.010$ & $\mathrm{H}=8.4,3 \mathrm{df}, p=0.039$ \\
Branch of nursing & $\mathrm{H}=13.4,2 \mathrm{df}, p=0.001$ & $\mathrm{H}=6.3,2 \mathrm{df}, p=0.043$ & $\mathrm{H}=13.9,2 \mathrm{df}, p=0.001$ \\
\hline
\end{tabular}

\subsection{Experience with computers}

Two aspects of experience were surveyed; the use respondents made of computers and the amount of time spent on eight activities. There were differences in respondents' experience by demographics and over time. Respondents reported a greater increase in experience between Baseline and T1. The differences were statistically significant between Baseline and T1 ( $\mathrm{Z}=-3.3, p=0.001)$ and Baseline and T2 $(\mathrm{Z}=-3.3, p=0.001)$ but not between $\mathrm{T} 1$ and $\mathrm{T} 2$. The outliers were all BME respondents on the DipHE programme (Figure 3). Respondents on the DipHE programme, those with NVQ, HNC, HND qualifications and those who were BME or aged 36 years or older reported the least experience at Baseline but there was convergence by $\mathrm{T} 2$.

There were significant changes between Baseline and $\mathrm{T} 1$ in the reported use of computers for education by all respondents (Z=-3.6, $p<0.0005$ ) but not between $\mathrm{T} 1$ and $\mathrm{T} 2$. 


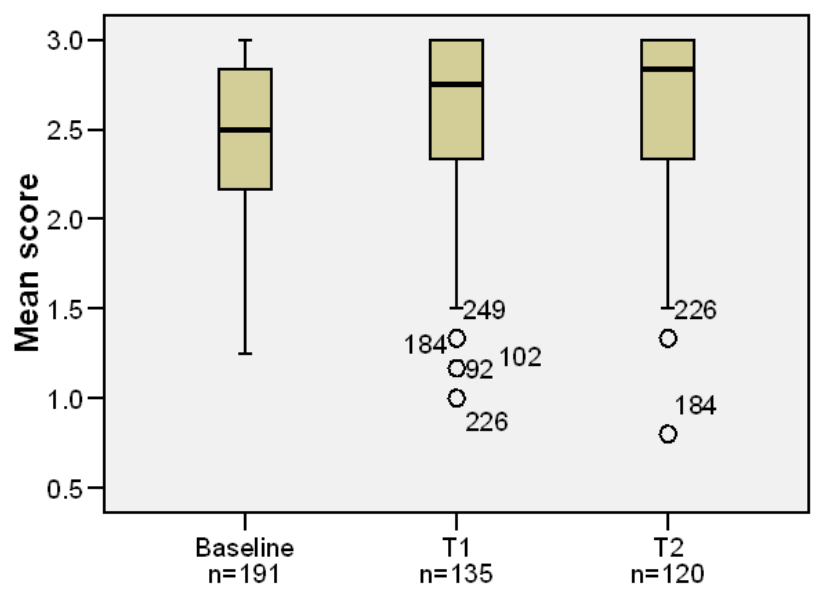

Figure 3. Experience using computers

\subsection{Attitude to computers in education}

Respondents' reported attitudes to computers in education (10 items) did not change consistently over time. When the mean scores of respondents at each time point were plotted (see Figure 4), it emerged that attitude became significantly more positive between Baseline and $\mathrm{T} 1(\mathrm{Z}=-2.2, p=0.028)$ but was slightly less positive at $\mathrm{T} 2$. This decrease was not statistically significant.

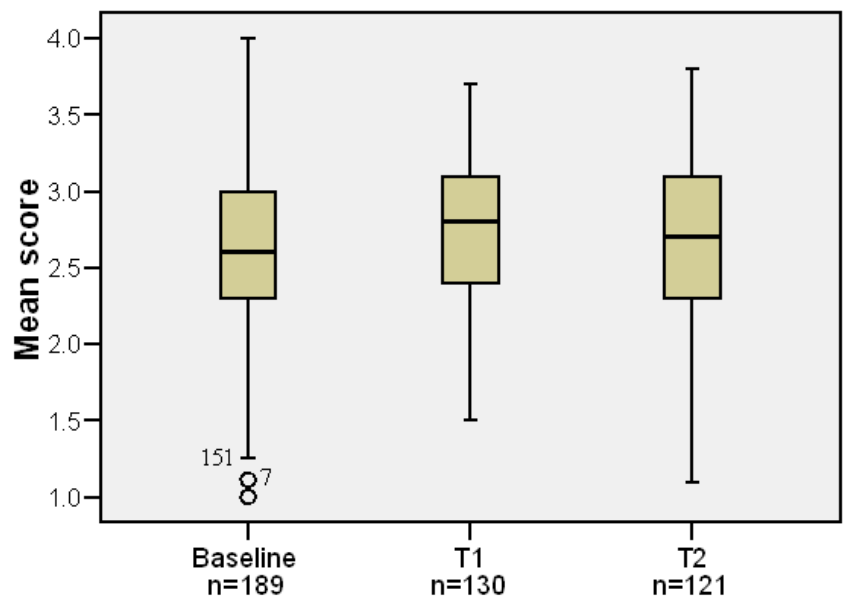

Figure 4. Attitude to computers in education

There were significant differences between ethnic groups on their reported attitude to computers in education at Baseline $(\mathrm{H}=19.4,1 \mathrm{~d} f, p<0.0005)$ and at $\mathrm{T} 2(\mathrm{H}=7.6,1 \mathrm{~d} f, p=0.006)$ (see Figure 5). BME respondents reported more positive attitudes at all time points and showed little change across the time points. White respondents, in contrast, shifted their response at each time point. They held significantly less positive views at Baseline, reported more similar views to BME respondents at T1 and then reported less positive attitudes at T2. No other demographic differences were present. 


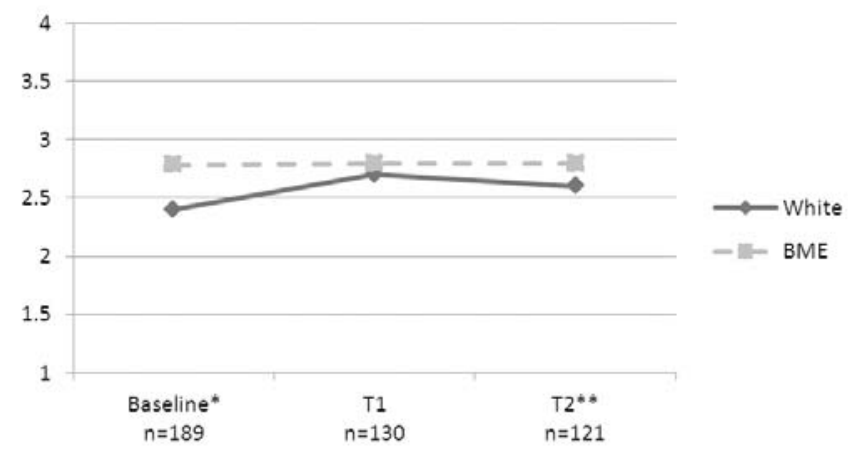

Figure 5. Attitude to computers in education and ethnicity

\subsection{Analysis of variance}

Two-way ANOVAs were performed on the ranked scores to establish whether there were relationships between ICT skills, confidence with computers, attitude to ICT in education and experience with computers and the demographic factors that have already been discussed. This analysis demonstrated irregular interactions and larger samples would be required to identify the existence of relationships.

\subsection{Summary of findings}

The greatest differences between groups were found at Baseline and use and acceptance remained somewhat different at T1, however, by T2 there was some convergence. There was variation by programme, age, prior education, ethnicity and Branch of nursing concerning aspects of confidence, skill and attitude to ICT and ICT in education. The data indicated greater change between Baseline and T1. There were, however, positive and negative movements at each time point. Comparative analysis using the demographic variables showed that there were significant differences within the sample. A key variable appeared to be ethnicity with prior education, programme and age possibly interacting. The numbers of cases in some groups were small so that this finding warrants further exploration.

\section{Discussion}

This study is one of the first to explore and provide insights into how nursing students vary in their experience of ICT and the trajectory of their development of ICT literacy over the first year. In addition, it provides some indication of the difference between the responses to ICT of students who take direct routes from school to university and those who are mature or enter nurse education through widening participation routes. The discussion will focus on three key areas, namely: reported confidence and skills of respondents with ICT; their experience as their education progresses; and their views on the use of ICT for education. Finally, the implications for nurse education and study limitations will be addressed.

\subsection{Confidence and skills of respondents with ICT}

Nursing students reported differing levels of confidence in their ICT skills on arrival at university. During year one their reported confidence increased but the nature of this change varied. There are indications that the ICT skills development of nursing students has been largely incidental, with substantial variation in how the development of these skills has been embedded into curricula despite information literacy being regarded an important skill for contemporary nurses ${ }^{[4,35,36]}$. This study identified a sub-group of skills, which broadly encompassed the basic competencies to meet the international indicators of information literacy proposed by Catts and Lau ${ }^{[2]}$. However, newly enrolled nursing students need to develop 
the ICT skills necessary to engage with evidence to inform practice which are less likely to have been part of their prior educational experience. They also need to perceive that this is essential to their future career ${ }^{[37,38]}$.

Recent UK reports ${ }^{[26,39,40]}$ have identified the development of both student and staff ICT skills as a priority for enabling online learning. Cooke ${ }^{[39]}$ has concluded that, although students were very able to use the Internet, the evidence indicates that they were not good at information finding or critical appraisal of information; a finding reiterated in the recent Ipsos MORI surveys ${ }^{[41]}$. There is also some evidence that students will make use of only those technologies with which they feel comfortable and familiar ${ }^{[38,41,42]}$ and that fit with their lifestyle and their learning strategies ${ }^{[38,42]}$. This suggests that, where students are asked to use ICT in unfamiliar ways or where they cannot observe an immediate advantage, they may be more resistant. Adjustment to the requirements of using and applying ICT appeared to take place during the first six months of university education. What constitutes basic ICT literacy, however, does not remain static. Technology is always advancing and tests nursing students' ability to acquire new skills and the skill development of teaching staff ${ }^{[35,40]}$. From the results of this study, a skill trajectory was developed to demonstrate the pathway from novice to competent information managers able to integrate a number of skills and apply them to support their education (see Figure 6). The skills in the lower quadrants represent those that the majority of students reported utilising either in their education or leisure pursuits. The upper quadrants represent those skills needed for education which were not widely reported or which students were reported limited confidence in undertaking. Equally, the further right the activity is placed the quadrant the greater the combination of skills required to achieve.

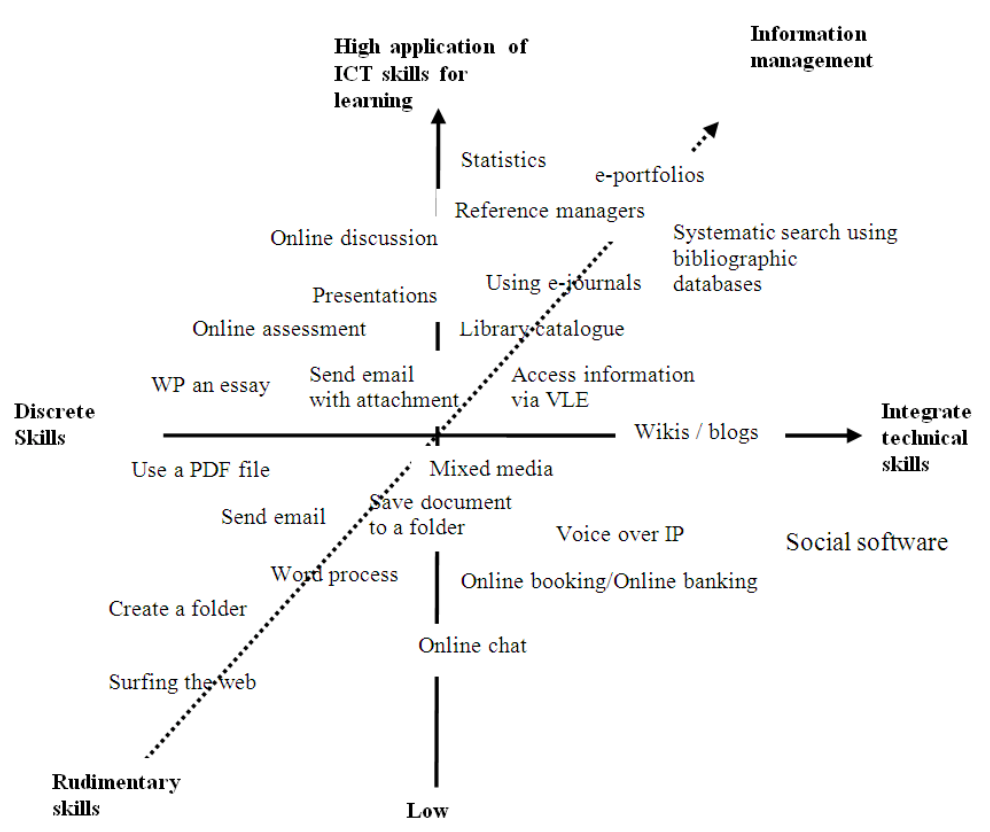

Figure 6. Development of ICT skills for learning

\subsection{The experience of first year pre-registration nursing students with ICT}

The nursing students in this study reported differing ICT experience as they entered university and reported an expanded range of computer use at each successive time point with a significant increase being noted from Baseline to T1. Cross-sectional studies, from the US and Australia respectively ${ }^{[4,43]}$ have found that registered nurse respondents had more experience with computers than pre-registration nursing students. This is congruent with our findings, where respondents with prior degrees reported broader ICT experience. Initially, respondents' prior educational experience was 
related to their ICT experience. There was some evidence in this study that those with a conventional education experience had greater ICT experience regardless of age at baseline, but this was not evident at subsequent time points. The respondents most comfortable with computers at entry were the 20-35 year old quartile. This finding appeared to challenge notions that younger students are 'digital natives' ${ }^{[44]} \mathrm{W}$ with complete command and confidence in a repertoire of ICT skills a finding supported by Goodyear and Ellis ${ }^{[45]}$ who also rejected the claims that the 'net' generation enter higher education expecting to engage unconditionally with ICT. The uses made of computers and the Internet by this study's respondents changed and increased in diversity over the three time points, with the greatest increase between the first two survey points. This resonates with Shepherd and Bryson's ${ }^{[46]}$ findings that there was an association between higher levels of education and greater use of the Internet. Newly enrolled nursing students would appear to enter university and move through their first year on different trajectories with variation in their intensity of use but with more consistent opportunities to broaden their experience some convergence occurs.

\subsection{Nursing students' experience of using I CT for education}

The study respondents showed few clear patterns in their response to the use of ICT in education. This is of particular importance in view of the previous research findings that context has a strong influence on attitudes to using computers ${ }^{[47]}$. While the respondents recognised the place of ICT in education there appeared to be ambiguity about the exact form that this should take. The study respondents were surprised by the level of computer use in their programmes and feared that it would mean less face to face interaction with nurse educators. Nursing students entered university with very varied ICT skills and little expectation of using ICT in education. Indeed, a number of respondents indicated that they were initially surprised or unhappy about the need to engage with technology enhanced learning. This view is apparently widespread in the student population, at least for the youngest age group, and was confirmed by a JISC/IPSOS Mori survey ${ }^{[41]}$ of 17-19 year old student expectations and experiences of ICT and Levett-Jones et al. ${ }^{[38]}$. The JISC/IPSOS Mori ${ }^{[41]}$ study found that 17-19 year old students, while familiar with ICT and the Internet, expected to receive support with using it at university. Levett-Jones et al. ${ }^{[38]}$ also found that nursing students had a narrow range of skills and were confounded by the uses of ICT expected at university. Despite the much wider age range in the current study there were similar proportions struggling with ICT which may have implications for their educational progression. Further contemporary support for this finding emerged from a British Library/JISC study ${ }^{[48]}$ which found that, although students owned and were familiar with using technology, they lacked higher level information literacy and interpretative skills. Thus a consistent pattern is emerging of students who as they enter university are not prepared for the educational or professional use of ICT.

\section{I mplications for nursing education}

Nursing education takes place in a complex policy and practice environment. Nursing students are expected to become ICT competent as future nurses in the health service. In addition, as graduates of higher education they need to gain transferrable skills which they will use as they become lifelong learners accessing flexible and distributed learning to update their knowledge and skills. The UK NHS is the third largest employer in the world ${ }^{[49]}$ and there is growing tension between its ambition to provide workforce education and the traditional role of universities and colleges. Nurse educators need to build students' applied skills appropriate to the competence levels required at different stages of their careers for two reasons. Firstly, to help them develop ICT skills relevant to academic study and secondly, to introduce the ICT skills relevant to practice. The skills needed for academic study are: find, access, discuss, analyse, critique and, present information and data ${ }^{[2]}$. In contrast in practice skills include: data entry; data quality; informatics; problem solving approaches to using ICT, and the ability to act independently in the area of information literacy ${ }^{[2]}$; to transfer knowledge and skill from one setting to another ${ }^{[22]}$.

There is a tension between students and their perception of the very informal and creative use that is made of a range of social technologies developed for the web and the formalised legacy systems found in universities and hospitals. Smith ${ }^{[50]}$ in reviewing policy over the past 40 years observed that networks and technology extension had been the focus of major 
investment but staff development and student focused technologies were not being developed at the same pace. While there is work in progress to address these deficits, there is also a conflict between centralist approaches and informal social networking. Smith ${ }^{[50]}$ has mapped a time line which indicates that there have been shifts between centralist or managerial approaches to educational technology and individualistic approaches over time. Within universities there is currently a tendency for centralised management and the provision of managed learning systems developed to make administration of programmes more efficient and provide a consistent experience for all students. Students, however, may be accustomed to individualised use or have little experience of ICT and there is a risk that they will find the managed learning environment counter-intuitive and impersonal.

The use of technology pervades education and work, therefore, a failure of student socialisation to ICT for education would have implications beyond the university. These respondents will become the mentors and managers of future students and their attitudes to ICT will have an influence on how they perceive the nursing profession. In addition, they will experience expanding use of ICT in the workplace and when accessing post-qualification education.

\section{Study limitations}

The study site had one of the most diverse local population in the UK. It attracted an atypical nursing student population because of its location. There are, therefore, inevitable difficulties in extrapolating the findings to the wider population of nursing students. Although the overall response rate was reasonable, the repeat response rate for the three time points was low, which means that there were limits to the trend analysis which could be undertaken. A further limitation of this survey design was the dependence on self reporting without the triangulation of results with a knowledge test. The combining of ethnic groups ${ }^{[34]}$ limits the inferences which can be made about any cultural group. While it was interesting and potentially useful to have a very diverse population from which to draw, this also resulted in certain challenges relating to the interpretation of the study findings. The rapid advances in technology mean that, for future use, the survey instrument will need further validation, and refinement, and must be reconsidered in the context of the competencies expected of a newly registered nurse at a given point in time.

\section{Conclusion}

The recent history of nurse education has involved continuous change and development. This study, however, took place at a time when transformation in both the education environment and health settings was accelerating. The study respondents entered the nursing profession at a time of rapid technological change with significant policy initiatives being introduced concerning the health service and e-learning. Nursing students could not anticipate the impact of these as they entered their education and were puzzled by the dissonance that they experienced. The study findings suggest that attention needs to be paid within curricular planning as to how nursing students manage the entry to university and practice. Different groups of students may need different activities to develop their use and incorporation of ICT skills for education. The challenge remains to reach the point where the technology becomes transparent ${ }^{[51]}$ in the same manner that, for example, mobile phones have. Currently the pace of change with technology is advancing so rapidly that it is very difficult to predict and plan for future skills profiles. How students negotiate the boundary between pre-university ICT and that used in universities and the health services will depend on the interaction of a range of factors as they move through induction and acclimatisation to nurse education.

\section{Acknowledgement}

The authors acknowledge the support of Peter Milligan, Senior Applications Analyst Advisor at King’s College London with statistical analysis. 


\section{References}

[1] UNESCO. Towards and Information Literate Society: Prague Declaration. 2003. Available from:

http://portal.unesco.org/ci/en/files/19636/11228863531PragueDeclaration.pdf/PragueDeclaration.pdf.

[2] Catts R \& Lau J. Paris: UNESCO. Towards Information Literacy Indicators. 2008. Available from: http://www.uis.unesco.org/Library/Documents/wp08_InfoLit_en.pdf

[3] Johnson L Levine A Smith R and Stone S. The 2010 Horizon Report. Austin, Texas: The New Media Consortium. 2010. Available from: http://www.nmc.org/publications/horizon-report-2010-higher-ed-edition

[4] Eley R Fallon T Soar J Buikstra E and Hegney D. The status of training and education in information and computer technology of Australian nurses: a national survey. Journal of Clinical Nursing. 2008; 17: 2758-2767. http://dx.doi.org/10.1111/j.1365-2702.2008.02285.x

[5] Bond CS. Guest editorial: Nurses' requirements for information technology: A challenge for educators. International Journal of Nursing Studies. 2007; 44: 1075-1078. http://dx.doi.org/10.1016/j.ijnurstu.2007.01.009

[6] Hall W. Whither nursing education? Possibilities, panaceas, and problems. Nurse Education Today. 2009; 29: 268-275. http://dx.doi.org/10.1016/j.nedt.2008.09.005

[7] Rich KL and Nugent KE. A United States perspective on the challenges in nursing education. Nurse Education Today. 2010; 30: $228-232$. http://dx.doi.org/10.1016/j.nedt.2009.10.015

[8] Salminen L Stolt M Saarikoski M Suikkala A Vaartio H and Leino-Kilpi H. Future challenges for nursing education - A European perspective. Nurse Education Today. 2009; 30: 233-238. http://dx.doi.org/10.1016/j.nedt.2009.11.004

[9] Rukholm EE Stamler LL Bednash G(P) Potempa K Macleod Clark J and Parfitt B. Scaling up the global nursing health workforce: Contributions of an international organization. Collegian. 2009; 16: 41-45. http://dx.doi.org/10.1016/j.colegn.2009.01.001

[10] Department for Education and Science Harnessing Technology Transforming Learning and Children’s Services. HMSO, London. 2005. Available from: https://www.education.gov.uk/publications/standard/publicationDetail/Page1/DFES-1296-2005

[11] Becta. Harnessing Technology Next Generation Learning. 2008. Available from: http://webarchive.nationalarchives.gov.uk/20060315075935/dfes.gov.uk/publications/e-strategy/.

[12] Higher Education Funding Council England (HEFCE). Enhancing learning and teaching through the use of technology: A revised approach to HEFCE’s strategy for e-learning. 2009. Available from: http://www.hefce.ac.uk/pubs/hefce/2009/09_12/.

[13] Department of Health. A framework for Technology Enhanced Learning. 2011. Available from: http://www.dh.gov.uk/en/Publicationsandstatistics/Publications/PublicationsPolicyAndGuidance/DH_130924

[14] Sharpe R Benfield G Lessner E and DeCicco E. Scoping study for the pedagogy strand of the JISC e-Learning Programme. Final Report 4.1. 2005. Available from: http://www.jisc.ac.uk/uploaded_documents/scoping study final report v4.1.doc.

[15] Creedy DK Mitchell M Seaton-Sykes P Cooke M Patterson E Purcell C et al. Evaluating a Web-Enhanced Bachelor of Nursing Curriculum: Perspectives of Third-Year Students. Journal of Nursing Education. 2007; 26(10): 460-467.

[16] Wilkinson A. While, AE. Roberts, J. Measurement of information and communication technology experience and attitudes to e-learning of students in the healthcare professions: integrative review. Journal of Advanced Nursing. 2009; 65 (4): 755-772. http://dx.doi.org/10.1111/j.1365-2648.2008.04924.x

[17] Ellenbecker CH. Preparing the Nursing Workforce of the Future. Policy Politics Nursing Practice. 2010; 11: 115-125. http://dx.doi.org/10.1177/1527154410380142

[18] Sinclair M and Gardner J. Planning for information technology key skills in nurse education. Journal of Advanced Nursing. 1999; 30(6): 1441-1450. http:/dx.doi.org/10.1046/j.1365-2648.1999.01229.x

[19] Mattheos N Nattestad A Schittek M and Attström R. Computer literacy and attitudes among students in 16 European dental schools: current aspects, regional differences and future trends. European Journal of Dental Education. 2002; 6: 30-35.

[20] Dorup J. Experience and attitudes toward information technology among first year medical students in Denmark: longitudinal questionnaire survey. Journal of Medical Internet Research. 2004; 6(1). Available from: http://www.jmir.org/2004/1/e10/.

[21] Adams A and Timmins F. Students views of integrating web-based learning technology into the nursing curriculum. Nurse Education in Practice. 2006; 6(1): 12-22. http://dx.doi.org/10.1016/j.nepr.2005.05.005

[22] Staggers N Gassert CA and Curran C. Informatics competencies for nurses at four levels of practice. Journal of Nursing Education. 2001; 40(7): 303-316.

[23] Cragg CE Edwards N Yue Z Xin S and Hui ZD. Integrating web-based technology into distance education for nurses in China: Computer and Internet access and attitudes. CIN: Computers Informatics Nursing. 2003; 21(5): 265-274.

[24] Honey M. Flexible learning for postgraduate nurses: a basis for planning. Nurse Education Today. 2004; 24 : $319-325$. http://dx.doi.org/10.1016/j.nedt.2004.02.006

[25] Gillen J Barton D. Digital Literacies: A Research Briefing by the Technology Enhanced Learning Research Programme. TLRP/ESRC/ESPRC. 2010. Available from: http://www.tlrp.org/docs/DigitalLiteracies.pdf

[26] Brindley L. Collaborate to compete: Seizing the opportunity of online learning for UK higher education Report to HEFCE by the Online Learning Task Force 2011. Available from: http://www.hefce.ac.uk/pubs/year/2011/201101/ 
[27] Jacobsen HE Andenæs R Third year nursing students' understanding of how to find and evaluate information from bibliographic databases and Internet sites. Nurse Education Today. 2011; 31: 898-903. http://dx.doi.org/10.1016/j.nedt.2011.01.003

[28] Brettle A Raynor M. Developing information literacy skills in pre-registration nurses: An experimental study of teaching methods. Nurse Education Today 2012 In press 7 pages http://dx.doi.org/10.1016/j.nedt.2011.12.003

[29] Barakzai MD and Fraser D. The effect of demographic variables on achievement in and satisfaction with online coursework. Journal of Nursing Education. 2005; 44(8): 373-380.

[30] Nursing \& Midwifery Admissions Service (NMAS). Statistical Report 2004. 2005. Available from: http://www.nmas.ac.uk.

[31] UCAS. Online statistical data. 2005. Available from: http://www.ucas.ac.uk/he_staff/stat_services1/.

[32] Wilkinson A. Roberts J. While AE. Construction of an instrument to measure student information and communication technology skills, experience and attitudes to e-learning. Computers in Human Behavior. 2010; 26: 1369-1376. http://dx.doi.org/10.1016/j.chb.2010.04.010

[33] SPSS, 2007. SPSS Statistics Release 12-15. SPSS.

[34] Malley-Morrison K and Hines DA. Attending to the Role of Race/Ethnicity in Family Violence Research Journal of Interpersonal Violence. 2007; 22(8): 943-972. http://dx.doi.org/10.1177/0886260507303060

[35] McNeil BJ Elfrink V Beyea SC Pierce ST and Bickford CJ. Computer literacy study: report of qualitative findings. Journal of Professional Nursing. 2006; 22(1): 52-59. http://dx.doi.org/10.1016/j.profnurs.2005.12.006

[36] Royal College of Nursing (RCN). Finding, using and managing information: Nursing, midwifery, health and social care information literacy competencies. 2011. Available from: http://www.rcn.org.uk/_data/assets/pdf_file/0017/357020/003847.pdf.

[37] Bond CS. Nurses, computers and pre-registration education. Nurse Education Today. 2009; 29(7): 731-734. http://dx.doi.org/10.1016/j.nedt.2009.02.014

[38] Levett-Jones T Kenny R Van der Riet P Hazelton M Kable A Bourgeois S et al. Exploring the information and communication technology competence and confidence of nursing students and their perception of its relevance to clinical practice. Nurse Education Today. 2009; 29: 612-616. http://dx.doi.org/10.1016/j.nedt.2009.01.007

[39] Cooke R. DIUS. On-line Innovation in Higher Education. 2008. Available from: http://www.dius.gov.uk/policy/documents/online_innovation_in_he_131008.pdf.

[40] Committee of Inquiry into the Changing Learner Experience (CICLE). Higher Education in a Web 2.0 World. 2009. Available from: http://www.jisc.ac.uk/media/documents/publications/heweb20rptv1.pdf.

[41] Ipsos MORI. Great Expectations of ICT how Higher Education Institutions are measuring up. 2008. Available from: http://www.jisc.ac.uk/publications/research/2007/studentexpectations.aspx.

[42] Creanor L Gowan D Howells C and Trinder K. Glasgow Caledonian University and Open Learning. L E X The Learner Experience of e-Learning. Final Project Report. 2006. Available from: http://www.jisc.ac.uk/uploaded_documents/LEX\%20Final\%20Report_August06.pdf.

[43] Bloom KC and Hough MC. Student satisfaction with technology enhanced learning. CIN: Computers, Informatics Nursing. 2003; 21(5): 241-246.

[44] Prensky M. Digital Natives, Digital Immigrants. On the Horizon NCB University Press. 2001; 9(5). Available from: http://www.marcprensky.com/writing/Prensky\%20-\%20Digital\%20Natives,\%20Digital\%20Immigrants\%20-\%20Part1.pdf.

[45] Goodyear P and Ellis RA. University students' approaches to learning: rethinking the place of technology. Distance Education. 2008; 29(2): 141-152. http://dx.doi.org/10.1080/01587910802154947

[46] Shepherd A and Bryson I. Household and individual use of the Internet. Chapter 2 in Focus on the Digital Age. ONS. 2006. Available from: http://www.ons.gov.uk/ons/rel/social-trends-rd/focus-on-the-digital-age/2007-edition/focus-on-the-digital-age---focus-on-the-digital-age -report.pdf .

[47] Kay RH. An exploration of theoretical and practical foundations for assessing attitudes toward computers: The Computer Attitude Measure (CAM). Computers in Human Behavior. 1993; 9: 371-386.

[48] Williams P and Rowlands I. Information Behaviour of the Researcher of the Future. 2008. Available from: http://www.jisc.ac.uk/media/documents/programmes/reppres/gg_final_keynote_11012008.pdf.

[49] NHS. About the NHS. 2009. Available from: http://www.nhs.uk/aboutnhs/Pages/About.aspx.

[50] Smith J. From flowers to palms: 40 years of policy for online learning. ALT-J. 2005; 13 (2): 93-108. http://dx.doi.org/10.1080/09687760500104054

[51] Lave J, Wenger E (1991) Situated Learning: Legitimate Peripheral Participation. Cambridge University Press. 